\title{
Phytoplankton Composition at Jeddah Coast-Red Sea, Saudi Arabia in Relation to some Ecological Factors
}

\author{
Hussein E. Touliabah ${ }^{1}$, Wafaa S. Abu El-Kheir ${ }^{1}$, Mohammed \\ Gurban Kuchari ${ }^{2}$ and Najah Ibrahim Hassan Abdulwassi ${ }^{3}$ \\ ${ }^{1}$ Botany Dept., Faculty of Girls, Ain Shams University, Cairo, \\ Egypt, ${ }^{2}$ Faculty Science, King Abdulaziz University, and \\ ${ }^{3}$ Faculty of Girls, King Abdulaziz University, \\ Jeddah, Saudi Arabia.
}

\begin{abstract}
Phytoplankton succession in relation to some physicochemical characters of some water bodies at Jeddah Coast (Saudi Arabia) was studied for one year (2004). The sampling program included four different areas, North Obhour, Technology area, Down Town area and South Jeddah Area. Water samples were analyzed for some physico-chemical parameters (Temperature, $\mathrm{pH}, \mathrm{S} \%$, Dissolved Oxygen (DO), Calcium $\left(\mathrm{Ca}^{+2}\right) \&$ Magnesium $\left(\mathrm{Mg}^{+2}\right)$, Nitrite $\left(\mathrm{NO}_{2}\right)$, Nitrate $\left(\mathrm{NO}_{3}\right)$, Ammonia $\left(\mathrm{NH}_{3}\right)$, Reactive Orthophosphate $\left(\mathrm{PO}_{4}\right)$ and Reactive Silicate $\left(\mathrm{SiO}_{3}\right)$ as well as phycological parameters (Phytoplankton communities and Chlorophyll a).

The Jeddah Coast was found to be oligotrophic ecosystem in some areas, while some of these areas were mesotrophic with high phytoplankton density such as the Down Town and South Jeddah areas. The results showed that, the high phytoplankton density attaining the maximum of $2623.2 \times 10^{3} / \mathrm{m}^{3}$ at Down Town area during spring and the minimum of $118.7 \times 10^{3} / \mathrm{m}^{3}$ at Technology area during winter.
\end{abstract}

Seventy three species belonging to 73 genera and 5 groups were recorded. Dinophyceae was the first dominant group forming $43.8 \%$ of the total phytoplankton communities followed by Bacillariophyceae 27.9\%. Ceratium sp, Amphora ovalis, Pleurosigma salinatum, Trichodesmium sp and Synochoccus sp were tolerant species and considered as eutrophic indicators. 


\section{Introduction}

The Red Sea is a narrow inland sea separating the Arabian Peninsula, western Asia, from northeastern Africa. It extends northwest from the strait of Bab el Mandeb to Suez, Egypt, for a distance of 1,900 km (1,200 mile). The maximum depth of the sea is $3,040 \mathrm{~m}(9,970 \mathrm{ft})$, and its maximum width is $350 \mathrm{~km}(220$ mile). The northern extremity is divided by the Sinai Peninsula into the gulfs of Suez and Aqaba. The Suez Canal connects the Red Sea with the Mediterranean Sea and Bab El-Mandeb connects it with the Gulf of Aden, an arm of the Arabian Sea. Its ports are presented by Jeddah of Saudi Arabia, Mukalla of Yemen and Suez located at the Gulf of Suez, which are important for the traffic of the Red Sea ${ }^{[1]}$.

The seasonal variations of the algal flora in the different water sources in Saudi Arabia in relation to physico-chemical properties specially in the Red Sea had been studied by few authors ${ }^{[2-5]}$. Aleem et al.$^{[5]}$ recorded 16 species of blue green algae and 27 species of chlorophyta at the area of Obhour, in vicinity of Jeddah. Furthermore, they recorded new algal species in the Red Sea for the first time. These species were, Chrocoocus turgidus, Microcoleus chihonuplastes, Symplca muscorum, Tydemania expeditionis, Padina boyryana, Dictyopteris delicatula and Asterocystis ramose.

Recently, Abdulaziz et $a l^{[6]}$ recorded 35 genera of phytoplankton representing diatoms, Dinoflagellates and blue green algae of the Arabian Gulf of coastal waters of Saudi Arabia. They reported that, blooming of phytoplankton occurred during May and August, induced by changes in temperature and nutrients especially during summer seasons. Khomayis and Al$\mathrm{Harbi}^{\left[{ }^{7]}\right]}$ studied the species composition of the benthic phytoplankton of marine fouling area of Sharm Obhour (North Obhour), they recorded 22 species of Bacillariophyceae, 2 species of Cyanophyceae and 2 species of Dinophyceae. They concluded planktonic diatoms, as Cosinodiscus sp. and Nitzchia closterium were observed permanently throughout the year of investigation while Naviula sp. was not detected during summer. They reported also that the Trichodesmium sp. was the leader species of the Red Sea.

Khomayis ${ }^{[8]}$ studied the annual cycle of nutrient salts and chlorophyll-a in the coastal water of Jeddah, Red Sea. He studied area extended from South Corniche in South of Jeddah to North Obhour. He reported that, high nutrients content was accompanied by low phytoplankton biomass during summer. In addition, inorganic micro-nutrients considered as limiting factors affecting the growth of phytoplankton.

Seeberg-Elverfeldt et $a .^{[9]}$ reported that, that the genera Bacteriastrum, Chaetoceros, Nitzschia and Rhizosolenia were the most dominant genera of the 
diatom assemblage. The diatoms dominate the other planktonic and benthic algal groups during winter, in Jeddah Coast, Saudi Arabia.

The aim of the present work was to follow the changes that might take place in the standing crop and community structure of the phytoplankton in coastal water of Jeddah (Saudi Arabia) in response to changes in the physico-chemical characters of water.

\section{Materials and Methods}

Four locations of different ecological conditions have been chosen, North Obhour area, Technology area, Down Town area and South Jeddah (Fig. 1). These areas are located between latitudes of $21^{\circ} 22^{\prime} 00^{\prime \prime} \& 21^{\circ} 40^{\prime} 00^{\prime \prime}$ North and longitudes of $39^{\circ} 07^{\prime} 00^{\prime \prime} \& 39^{\circ} 10^{\prime} 00^{\prime \prime}$ East. The samples were collected from subsurface water seasonally (2004) from these four areas. The data represents the average of sites of each location.

\section{Physical, Chemical and Biological Parameters}

Physico-chemical parameters were carried out according to Standard Methods For Examination of the Water and Wasterwater $\left(\mathrm{APHA}^{[1 \mathbf{0}]}\right)$ which including temperature (air \& water), $\mathrm{pH}, \mathrm{DO}, \mathrm{Ca}^{+2}, \mathrm{Mg}^{+2}, \mathrm{NO}_{2}, \mathrm{NO}_{3}-\mathrm{N}, \mathrm{NH}_{3}$, $\mathrm{PO}_{4}$ and $\mathrm{SIO}_{3}$ and chlorophyll a.

\section{Phytoplankton}

Drop method was applied for counting and identification of phytoplankton species from different samples $\left(\mathrm{APHA}^{[10]}\right)$. Counting and identification were carried out by using Motic microscope at magnification of x400 \& x1000 provided with a digital camera. Phytoplankton counts were expressed as number of cells $X 10^{3}$ per $\mathrm{m}^{3}$ for all phytoplanktonic groups except Cyanophyceae. The filamentous and colonial forms of blue-green algae have been expressed as number of organisms $\times 10^{3}$ per $\mathrm{m}^{3}$.

Identification was carried out according to: Starmach, $1966^{[11]}$, Cornelius, $1971^{[12]}$; Garcia-Baptista, $1993^{[13]}$; Silva \& Pienaar, 2000 $0^{[14]}$ and Botes, $2003^{[15]}$.

\section{Statistical Analysis}

Preliminary analysis of the data was by matrix correlation analysis. Subsequently, the canonical correspondence analyses were performed with Multivariate Statistical Package (MVSP 3.12b) software (Kovach ${ }^{[16]}$ ). We carried out Canonical Corresponding Analysis (CCA) (Ter Braak, ${ }^{[17-18]}$ ) of the different phytoplanktonic groups with the available physico-chemical parameters. 


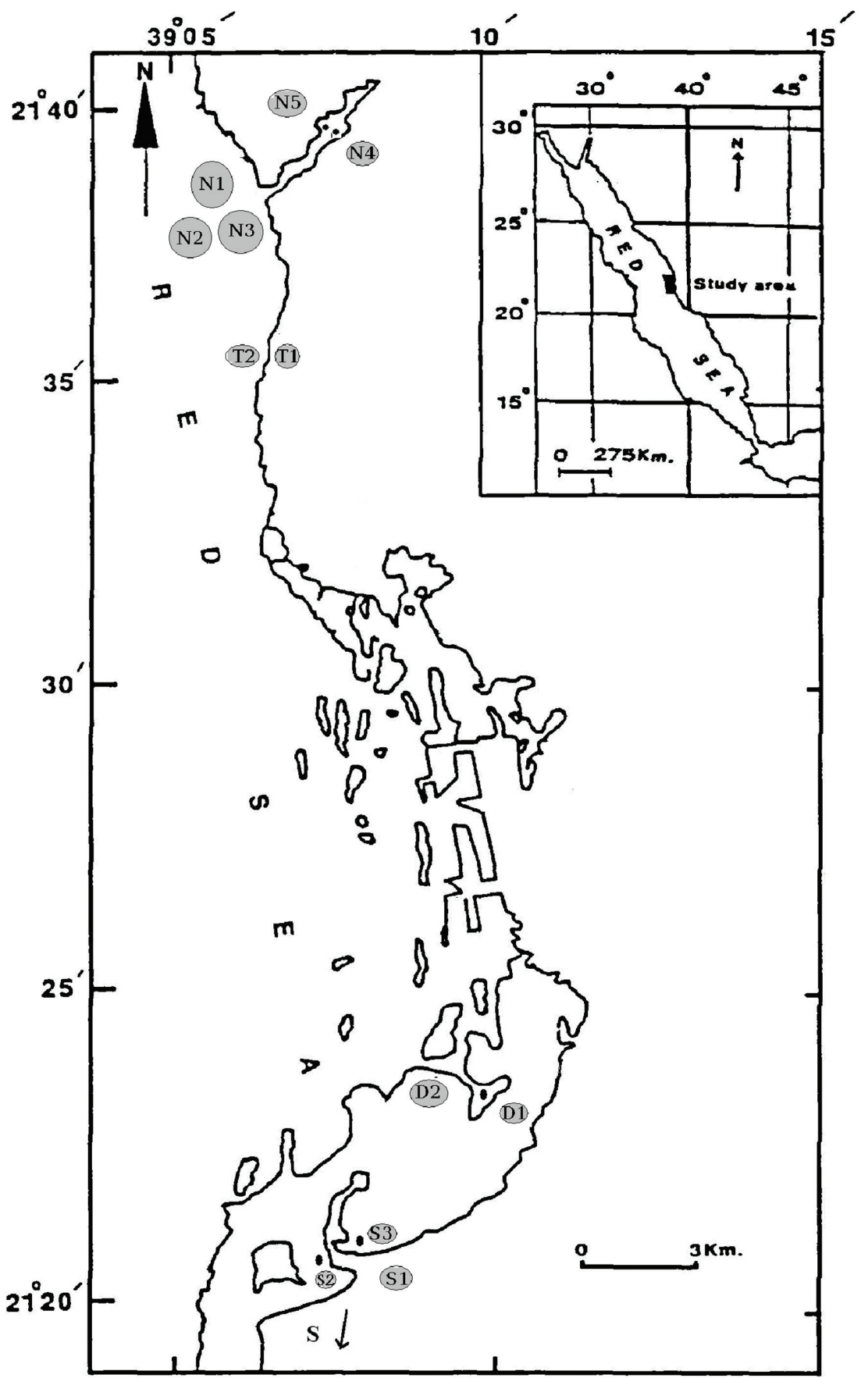

Fig. 1. Map showing the sampling sites of the investigated areas. 


\section{Results and Discussion}

The species composition of phytoplanktonic component follows a distinct succession regulated by physico-chemical characters of water such as mixing of water masses, $\mathrm{pH}$, light, temperature, turbulence, salinity and nutrients (Buzzi, $\left.{ }^{[19]}\right)$. Phytoplankton succession relevant to some physico-chemical characters of some water bodies at Jeddah (Saudi Arabia) was studied for one year (2004). The sampling program included different four locations, North Obhour, Technology area, Down Town area and South Jeddah Area (Fig. 1).

The results of air and sub-surface water temperature indicated that, water temperatures were always lower than corresponding air temperatures. Water temperatures were always lower than corresponding air temperature. The water and air temperatures were relatively low in winter $\left(21.9^{\circ} \mathrm{C} \& 26.7{ }^{\circ} \mathrm{C}\right)$ respectively, than summer $\left(35.3^{\circ} \mathrm{C} \& 42.8^{\circ} \mathrm{C}\right)$, respectively. The temperature values recorded during spring appeared to be suitable for algal growth, where the phytoplankton standing crop reached its maximum value. These data are in accordance of those of Kebede and Ahlgren ${ }^{[20]}$, they reported that the optimum temperature for phytoplankton growth is $30^{\circ} \mathrm{C}$.

The present study revealed that the $\mathrm{pH}$ values of the investigated sites lie on the alkaline side (Table 1). The $\mathrm{pH}$ values ranged between 8.70 at South Jeddah during spring and 6.97 at Down Town area during summer. These values appeared suitable for phytoplankton growth especially at South Jeddah during spring. The phytoplankton standing crops reached its maximum value of 2623.2 Cell $\times 10^{3} / \mathrm{m}^{3}$ at Down Town area in the same season where Dinophyceae, Bacillariophyceae and Cyanophyceae have their maximum growth at $\mathrm{pH} 8.04$ (Table 1). These data are in agreement with the findings of Qijun et al. ${ }^{[21]}$, they reported that the maximum growth of phytoplankton was observed at $\mathrm{pH}$ 7.5-8.0.

The dissolved oxygen "DO" values ranged from $1.67 \mathrm{mg} / \mathrm{l}$ at Down Town area during winter to $6.73 \mathrm{mg} / \mathrm{l}$ at the same area in spring. As a general trend, the lowest concentration of DO were detected in summer. This may be due to increasing water temperature and the decomposition of detritus plankton and organic matter, where by oxygen becomes consumed and carbon dioxide is produced. This result agrees with the fact that oxygen solubility decreases with increasing temperature and salinity (Calliari et al. ${ }^{[22]}$ ).

The Red Sea is a semi- enclosed system in which evaporation is one of the most important factors affecting salinity. Salinity is characterized by a remarkable variation, showed the highest value of $(80.50 \%)$ during summer at Technology area and the lowest value (35.25\%) at Down Town area during autumn (Table 1). The high value during summer may be attributed to the high evaporation rate as suggested by Schumann et al. ${ }^{[23]}$ and Khomayias ${ }^{[8]}$. Salinity showed a 
significant relation with both chlorophyceae and dinoflagellate which were abundant at these two sites. These two groups were rarely recorded during the present study and each of them was represented only by one species. This result confirmed the findings of Schumann et al. ${ }^{[23]}$, who concluded that salinity affects the phytoplankton diversity. In the present study, the correlation between salinity and chlorophyceae and chryptophycea were 0.61 for each one.

Table 1. Seasonal variations of some physico-chemical Parameters of the investigated locations along Jeddah Coast during 2004.

(N: North Obhour; T: Technology areas; D: Down Town and S: South Jeddah)

\begin{tabular}{|c|c|c|c|c|c|c|c|c|c|}
\hline Season & Area & $\mathrm{pH}$ & $\begin{array}{c}\mathrm{DO} \\
\mathrm{mg} / \mathrm{l}\end{array}$ & $\begin{array}{l}\text { S\%o } \\
\text { ppt }\end{array}$ & $\begin{array}{l}\mathrm{SiO}_{3} \\
\mu \mathrm{g} / 1\end{array}$ & $\begin{array}{c}\mathrm{Ca} \\
\mathrm{mg} / \mathrm{l}\end{array}$ & $\begin{array}{c}\mathrm{Mg} \\
\mathrm{mg} / \mathrm{l}\end{array}$ & $\begin{array}{l}\mathrm{PO}_{4} \\
\mu \mathrm{g} / 1\end{array}$ & $\begin{array}{l}\text { Total } \\
\text { Phyto* }\end{array}$ \\
\hline \multirow{4}{*}{$\begin{array}{c}\text { Winter } \\
2004\end{array}$} & $\mathrm{~N}$ & 8.11 & 5.70 & 43.16 & 3.03 & 33.56 & 114.68 & 5.15 & 141.3 \\
\hline & $\mathrm{T}$ & 7.96 & 5.18 & 56.00 & 6.93 & 50.15 & 181.00 & 2.97 & 118.7 \\
\hline & D & 7.85 & 1.67 & 37.50 & 5.21 & 30.10 & 97.15 & 31.32 & 528.8 \\
\hline & $\mathrm{S}$ & 8.33 & 3.20 & 52.13 & 8.79 & 76.53 & 222.47 & 1.51 & 162.9 \\
\hline \multirow{4}{*}{$\begin{array}{c}\text { Spring } \\
2004\end{array}$} & $\mathrm{~N}$ & 8.31 & 5.66 & 41.60 & 0.66 & 35.60 & 129.40 & 0.02 & 611.5 \\
\hline & $\mathrm{T}$ & 8.26 & 4.65 & 68.00 & 1.38 & 61.50 & 218.50 & 0.26 & 582.3 \\
\hline & D & 8.04 & 6.37 & 37.50 & 5.53 & 27.50 & $\mathbf{9 9 . 5 0}$ & 14.65 & 2623.2 \\
\hline & $\mathrm{S}$ & 8.70 & 5.87 & 69.67 & 1.29 & 62.00 & 264.33 & 0.88 & 695.3 \\
\hline \multirow{4}{*}{$\begin{array}{c}\text { Summer } \\
2004\end{array}$} & $\mathrm{~N}$ & 8.11 & 5.65 & 42.94 & 2.34 & 37.20 & 37.20 & $\mathbf{0 . 0 7}$ & 374.2 \\
\hline & $\mathrm{T}$ & 7.53 & 4.19 & 80.50 & 3.37 & 73.50 & $\mathbf{7 3 . 5 0}$ & 0.23 & 284.2 \\
\hline & D & 6.97 & 2.97 & 40.35 & 6.88 & 25.55 & 25.55 & 32.84 & 1501.5 \\
\hline & $\mathrm{S}$ & 7.93 & 2.99 & 72.40 & 6.87 & 49.00 & 49.00 & 20.20 & 752.5 \\
\hline \multirow{4}{*}{$\begin{array}{l}\text { Autumn } \\
2004\end{array}$} & $\mathrm{~N}$ & 8.13 & 5.56 & 41.48 & 3.46 & 39.40 & 134.20 & 0.55 & 345.1 \\
\hline & $\mathrm{T}$ & 7.99 & 4.92 & 60.50 & 4.26 & 68.50 & 195.00 & 0.00 & 135.7 \\
\hline & D & 8.10 & 2.07 & 35.25 & 7.18 & 27.50 & 105.00 & 20.81 & 522.0 \\
\hline & $\mathrm{S}$ & 7.99 & 3.38 & 57.67 & 6.77 & 66.67 & 240.67 & 0.26 & 151.3 \\
\hline
\end{tabular}

Cell no ${ }^{*}=$ No. of cells X $10^{3} / \mathrm{m}^{3}$

The present study revealed that calcium and magnesium showed their minimum concentrations $(25.55 \mathrm{mg} / \mathrm{l}$ for each) during summer at Down Town area where high values of phytoplankton standing crop were recorded (Table 1). Calcium and magnesium attained their maximum values $(76.53 \mathrm{mg} / \mathrm{l}$ and 264.33 $\mathrm{mg} / \mathrm{l}$ ) at South Jeddah during winter and spring, respectively. On the other hand, the lowest $\mathrm{Ca}$ and $\mathrm{Mg}$ concentrations observed during summer were accompanied by high phytoplankton standing crop value. These findings were in agreement with those of Farag-Afaf ${ }^{[24]}$ who attributed the decrease recorded in $\mathrm{Ca}$ and $\mathrm{Mg}$ to their consumption for chlorophyll synthesis, photosynthesis and metabolic reactions. 
In the present investigation, the highest silicate level $(8.79 \mu \mathrm{g} / \mathrm{l})$ was recorded at South Jeddah area during winter, whereas, the lowest silicate level $(0.66 \mu \mathrm{g} / \mathrm{l})$ was recorded during spring at North Obhour where diatoms showed a good flourishing (Table1). The irregular spatial pattern of silicate in coastal waters could be attributed to the growth and the uptake of silica by diatoms $(\mathrm{Wu}$ and $\mathrm{Chou}^{[25]}$ ). This irregular pattern of silicate may explain the lack of significant relation $(p>0.05)$ between silicate and any of the phytoplankton groups during the present study. Generally, the variations in silicate content are mainly influenced by mixing and stratification processes, physical and chemical characteristics of the environment rather than by diatom consumption (YousryKarima,$\left.{ }^{[26]}\right)$, as shown in the present investigation.

Data revealed that the highest $\mathrm{PO}_{4}$ levels of $(32.84$ and $31.32 \mu \mathrm{g} / \mathrm{l})$ were observed at Down Town area during summer and winter, respectively (Table 1), which could be related to reduced uptake rates by phytoplankton; this was confirmed by the reduced phytoplankton standing crop recorded at this area during the same seasons compared with the spring season where $\mathrm{PO}_{4}$ attained its lowest value $(14.65 \mu \mathrm{g} / \mathrm{l})$.

Nitrogen compounds were graphically presented in Fig. 2. Nitrite and ammonia attained their maximum values $(23.35 \mu \mathrm{g} / \mathrm{l}$ and $119.24 \mu \mathrm{g} / \mathrm{l})$, respectively at Down Town during summer, while nitrate reached its maximum value $(107.24 \mu \mathrm{g} / \mathrm{l})$ during winter at the same area. Nitrite was not detectable during spring and autumn at North Obhour, and during summer and spring at Technology area. On the other hand, nitrate was under the limit of detection at North Obhour during spring, summer and autumn.

Donatella ${ }^{[27]}$ reported that nutrients are mineral compounds which can have an adverse impact on water quality because of their ability to promote plant and algal growth. An excessive growth of aquatic plants can clog water ways and over stimulation of algae and microbes leads to an ecological process called eutrophication. Also, He reported that nitrogen and phosphorus compounds are considered to be the most essential for algal growth. The increase in the values of nutrients in the present study than those of Khomayias ${ }^{[8]}$, who reported lower values for his investigation and indicates more eutrophication along Jeddah coast. This may be attributable to domestic sewage, industrial point sources and pollution status. He also explained the high nitrate concentration by the decrease in its uptake and the possible decomposition of organic matter as well as oxidation of nitrite to nitrate. During the present study, the high levels of nitrite, nitrate and ammonia at the Down Town area (Fig. 2) were due to the domestic wastewater discharge. This is in agreement with the findings of El-Bassat \& Tyalor ${ }^{[28]}$, they reported that, nitrogen and phosphorus compounds are always present in domestic wastewaters. 


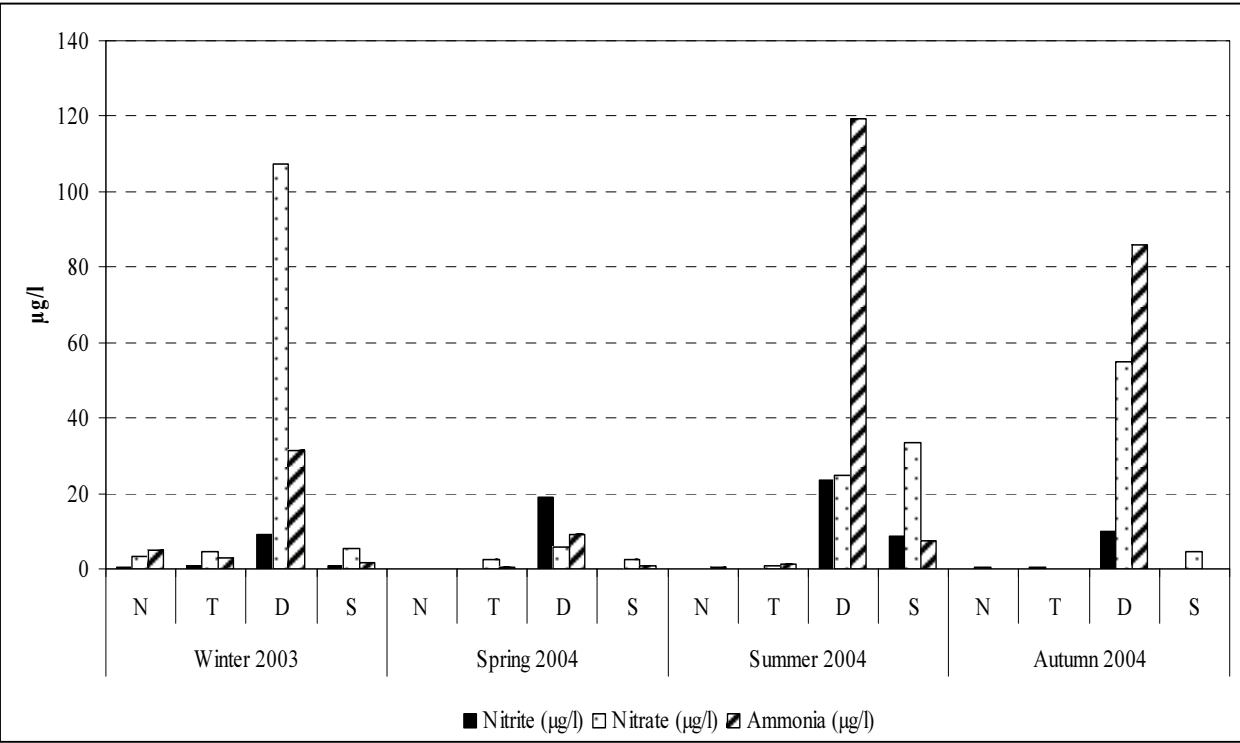

Fig. 2. Seasonal variations of Nitrite, Nitrate and Ammonia in the studied locations during the period of 2004.

Nitrite is one of the dissolved inorganic nitrogen forms present in water bodies and can be used as pollution indicator. Nitrite was nearly absent or present in trace quantities in water throughout the whole period of study, this could be resulted from the transformation to either nitrate or to ammonia. The negative correlation between $\mathrm{NO}_{3}$ and the total phytoplankton standing crop indicates the importance of nitrate as a source of nitrogen for phytoplankton growth (Yousry-Karima ${ }^{[26]}$ ). She pointed out that, the decrease in nitrate contents might be due to its utilization by phytoplankton. This phenomenon was found in the present study during spring season, where the nitrate concentration showed its lowest value and the total phytoplankton standing crop recorded the highest flourishment.

Camargo \& Alonso ${ }^{[29]}$ reported that inorganic nitrogen pollution in aquatic ecosystems stimulates the development, maintenance and proliferation of primary producers resulting in eutrophication of aquatic ecosystems. In additions, they reported the Cyanophyceae, Dinophyceae and diatoms appeared to be the major groups that may be stimulated by inorganic nitrogen pollution. This finding was in agreement with the present results, where Dinophyceae, Bacillariophyceae and Cyanophyceae were the dominant groups at Down Town. High concentrations of ammonia were found in Down Town area during summer, and not detectable during autumn at Technology area. 
The concentrations of chlorophyll (a) ranged between $1.01 \mu \mathrm{g} / \mathrm{l}$ at South Jeddah area during summer and $76.56 \mu \mathrm{g} / 1$ at Down Town area during autumn (Table 2). Total chlorophyll a revealed an increase at Down Town area all over the investigation period except summer. This result agrees with that of Khomayias $^{[8]}$ for the same area, he attributed that to higher levels of pollution resulting in increase of production. The direct significant relations $(\mathrm{p}<0.05)$ which were established between chlorophyll and nutrients during the present study were confirmed by Aktan et al., ${ }^{[30]}$.

Table 2. Seasonal variations of chlorophyll a $(\mu / \mathrm{l})$ in the investigated locations along Jeddah Coast during 2004.

\begin{tabular}{|c|c|c|c|c|}
\hline $\begin{array}{ll}\text { Studied area } & \text { Seasons } \\
\end{array}$ & Winter 2004 & Spring 2004 & Summer 2004 & Autumn 2004 \\
\hline North Obhour & 1.34 & 0.32 & 0.34 & 1.16 \\
\hline Technology area & 2.50 & 5.71 & 1.01 & 4.19 \\
\hline Down town & 17.23 & 44.96 & 2.15 & 76.56 \\
\hline South Jeddah & 5.14 & 4.35 & 1.05 & 3.13 \\
\hline
\end{tabular}

The phytoplankton community was represented by a total of 73 species belonging to 29 genera and 5 groups in the investigated areas namely, Dinophyceae, Bacillariophyceae, Cyanophyceae, Chlorophyceae and Chrysophyceae. During the present study, the most abundant groups were, Dinophyceae, Bacillariophyceae and Cyanophyceae and formed $43.80 \%$, $27.92 \%$ and $25.92 \%$ of the total phytoplankton standing crop, respectively (Fig. 3). Chlorophyceae and Chrysophyceae represented rare groups in the investigated areas with percentage frequency of $2.28 \%$ and $0.08 \%$ of the total phytoplankton respectively during the period of investigation (Fig. 4). The highest abundance of phytoplankton $\left(2623.2 \times 10^{3} \mathrm{Cells} / \mathrm{m}^{3}\right)$ was recorded at Down Town site during spring and minimum one $\left(118.75 \times 10^{3} \mathrm{Cells} / \mathrm{m}^{3}\right)$ was recorded at Technology area site during winter. In general the Down Town area showed higher average phytoplankton densities more than the other studied areas (Table1). This result agrees with Abdulaziz et al. ${ }^{[6]}$ for the gulf coastal waters of Saudi Arabia. The abundance of total phytoplankton along the investigated area followed the same trend of chlorophyll-a showing their maxima during spring which is considered the most productive season. Spring peaks of the phytoplankton at the Down Town area were mainly due to flourishing of Dinophyceae, which contributed $49 \%$ and $44 \%$ of the total phytoplankton community. 


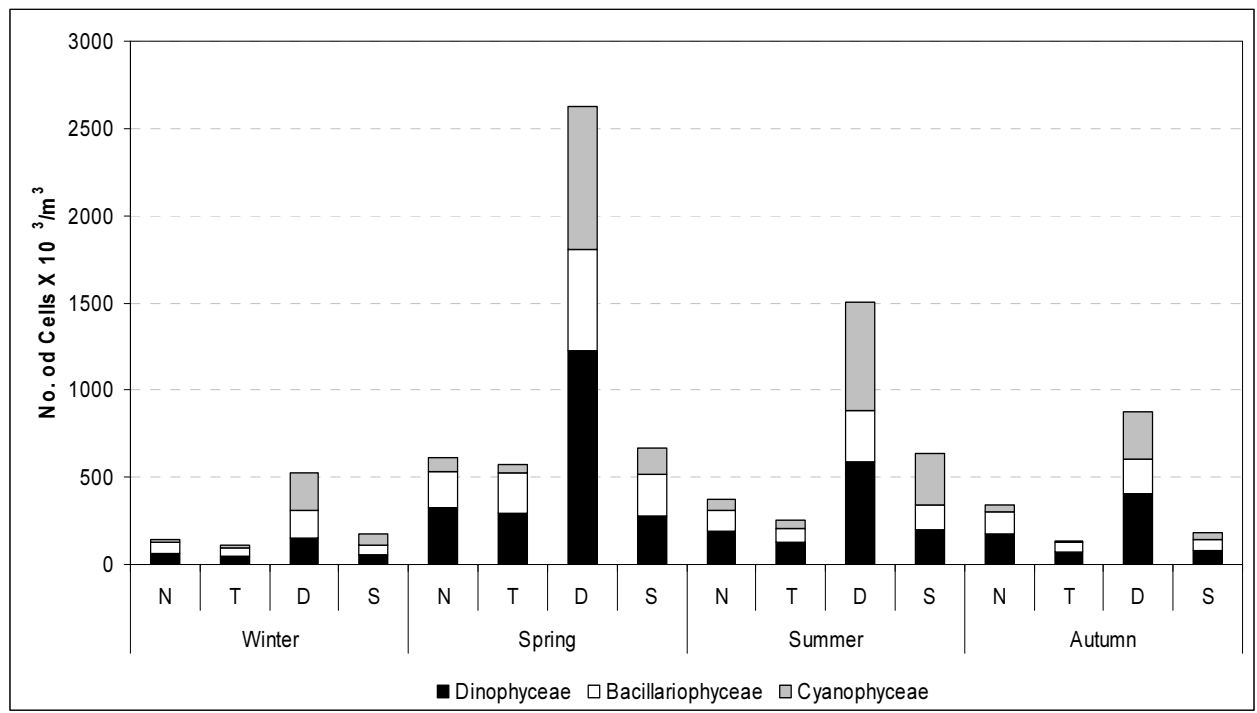

Fig. 3. Seasonal variations of dominant groups of phytoplankton in the studied locations along Jeddah Coast during 2004.

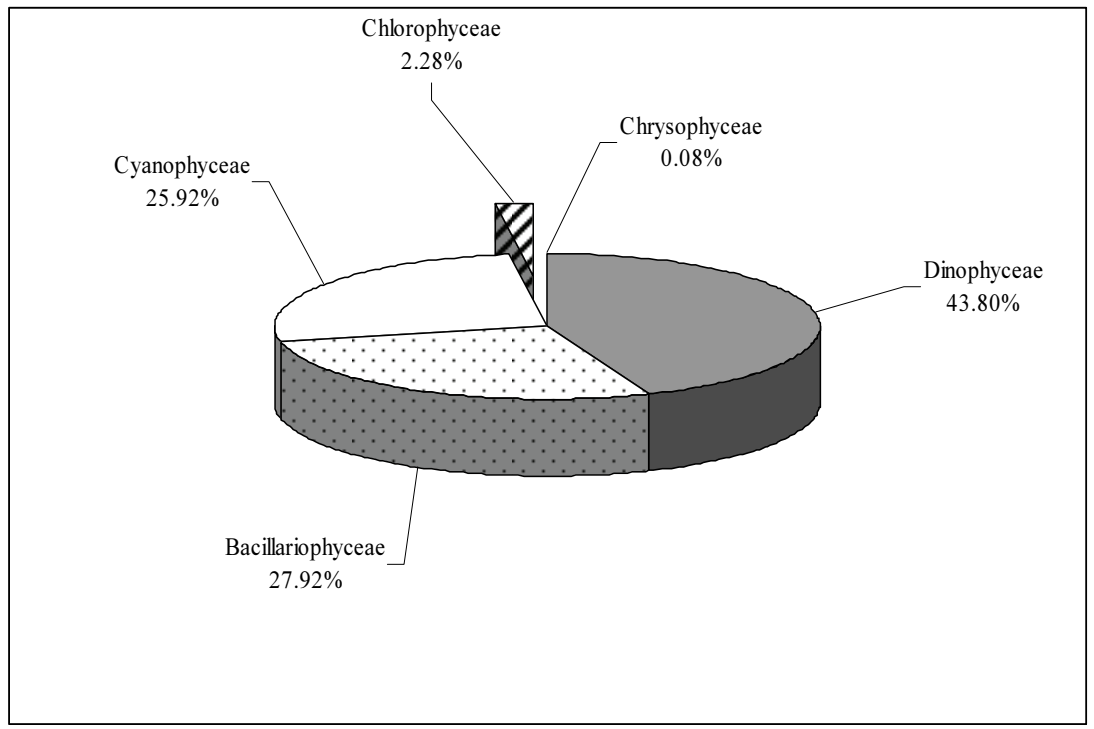

Fig. 4. The percentage abundance of the different algal group in the studied locations along Jeddah Coast during the period 2004.

The phytoplankton community composition in the study areas showed high standing crop values, whereas poor to some extent in the species number which may be attributed to the presence of some stressors that have limited the species diversity to only tolerant species to these environmental conditions (Parnell, ${ }^{[31]}$ ). 
During the period of investigation, Dinophyceae remained the fully elaborated group allover the year, except at the Down Town during winter and summer as well as at South Jeddah area during winter, where Cyanophyceae was the most dominant group. Twenty four species belonging to five genera were identified during the period of investigation. Dinophyceae was dominated by four species; Ceratium furca (Ehernberg), Prorocentrum micans, Ceratium fusus (Ehrenberg) Dujardin and Ceratium dens. They formed 17.29\%, 12.10\%, $10.27 \%$ and $8.28 \%$ of the total Dinophyceae, respectively. It was clearly noticed that Dinophyceae was the main component of the spring peak of the total phytoplankton with a highest population density in the Down Town area. This may be explained by high nutrient concentrations. The leading species of Genus Ceratium were responsible of the spring peak for the dinoflagellates during the present work. The same phenomenon was observed by Aktan et al. ${ }^{[30]}$, they attributed the high biovolume records in their study during spring to the big cell size of these Ceratium species.

Bacillariophyceae occupied the second predominance position where they contributed $27.9 \%$ of the total phytoplankton community (Fig.4). A total of 39 species belonging to 15 genera were identified in the study areas. The leading and abundant diatom species recorded during this investigation were: Nitzschia sigma (Kutz.) W. Smith, Melsoira granulate, Thalassiossira decipien, Thalassiossira hyaline, Cocconeis pediculus Ehrenberg and Cocconeis placentula Ehrenberg. They contributed 13.64\%, 12.94\%, 6.36\%, 6.03\%, 5.21\% and $4.24 \%$, respectively of the total Bacillariophyceae during the period of investigation. The maximum abundance of Bacillariophyceae was detected in spring recording $313.80 \times 10^{3}$ Cells $/ \mathrm{m}^{3}$ (Fig.3). The high nutrient load in the sewage water at the Down Town area was the main reason for the diatoms flourishment at this area. Varela and Pergo ${ }^{[32]}$ attributed the dominance of diatoms in the A Coruna Harbour (NW Spain) to the nutrient loaded sea water. Morais et $a l^{[33]}$ found that the increase in water temperature might have allowed phytoplankton especially diatoms to optimize its growth and productivity. Chaetoceros curviselum, Nitzschia longissima, N. sigma, Pleurosigma salinatum, Amphora laevis and Chaetoceros affine dominated the Bacillariophyceae during the present study. Flourishing of Chaetoceros sp. in spring was the main reason of the high population density of the Bacillariophyceae during this season.

Cyanophyceae was the third dominant group during the period of study, forming $25.9 \%$ of the total phytoplankton crop (Fig.4). Eight species belonging to seven genera were identified in this study. Three species dominated Cyanophyceae population during the present investigation. These species were Trichodesmium erythraeum Ehrenberg \& Gomont. Trichodesmium thiebautti Gomont and Synechococcus sp. They contributed by 26.5\%, 24.0\% and 16.0\% 
of the total Cyanophyceae, respectively along the investigated area. Cyanophyceae dominated other phytoplanktonic groups in South Jeddah location during summer, while it was absent at North Obhour during winter. Cyanophyceae attained two major peaks $816.45 \times 103$ Organisms $/ \mathrm{m} 3$ and $615.25 \times 10^{3}$ Organisms $/ \mathrm{m}^{3}$ in spring and summer respectively (Fig.3). This results matches with that of Millie et al. ${ }^{[34]}$ for St. Lucie River Estuary, Florida (USA), Totti et al. ${ }^{[35]}$ for the North Adriatic Sea and Chen ${ }^{[36]}$ for the South China Sea. Cyanophyceae were more frequent at the polluted Down Town and South Jeddah areas. During the present Trichodesmium sp. which is reported as cause of red tide phenomenon, was represented by two species; T. erythraeum and $T$. thiebautti. They flourished at North Obhour, constituting about $49 \%$ and $43 \%$ of the total Cyanophyceae, respectively. These two species were responsible for the spring and summer peaks. Genus Synechococcus flourished at Down Town and South Jeddah area, due to its tolerance for pollution. This species shares the responsibility of the spring and summer blooms with the genus Trichodesmium, since its frequency abundance reached $34 \%$ of the total Blue-Green algae at Down Town area.

Chlorophyceae was recorded with limited numbers during the period of investigation, it formed $2.3 \%$ of the total phytoplankton crop (Fig.4). Only one species belonging to one genera of these group was identified (Dunaliella sp.). The presence of Chlorophyceae was restricted to Technology area and South Jeddah area during winter and spring. Along Jeddah coast members of Chlorophyceae were rarely recorded during the present study. This result coincides with Chen ${ }^{[36]}$, for the South China Sea. Dunaliella sp was the only genus of Chlorophyceae observed during the present study. The presence of Chlorophyceae was restricted to the pool sites of the Technology area and South Jeddah area in all seasons. The occurrence of Dunaliella sp at the pool sites could be due to its ability to tolerate high salinity as confirmed statistically by the positive highly significant relation with salinity $(\mathrm{r}=0.7, \mathrm{p}<0.005)$. The same observation was reported by Taha et al. ${ }^{[37]}$ for the Egyptian coasts of the Red Sea. A positive significant relation was also found between Chlorophytes and calcium ion concentrations, which may explain the confined existence of this species to the pool sites. Celekli and Kulkoyluoglu ${ }^{[38]}$ recorded the relation between increased calcium ion concentrations as a result of building a concrete wall around pool in Turkey and flourishing of some phytoplankton species.

Chrysophyceae was scarcely presented. It formed a value of $0.08 \%$ of the total phytoplankton crop (Fig. 4). Only one species of Dictyocha octonaria belonging to one genera was identified during the period of investigation. The negligible contribution of flagellates in the phytoplankton community was reported in this investigation. Our data was similar to thos obtained by Varela and Prego ${ }^{[32]}$ at A Coruna Harbour- NW Spain. Presence of Chrysophyceae was 
confined at North Obhour area; Technology area and South Jeddah during the present study. Flagellates followed the same behavior of the Chlorophyceae, recording significant positive relations with temperature, salinity and calcium ion concentrations. The highest existence of flagellates in summer season at the pool site of the technology area was combined with low $\mathrm{pH}$ value.

The Canonical Coressponding Analysis (CCA) (Fig.5) was used to examine distribution pattern of the different phytoplankton groups along the investigated area. The ordination of CCA for the present study revealed that Cyanophyceae have a positive strong relationship with both orthophosphate and Nitrate, while a negative relation is reported between Cyanophyceae and dissolved oxygen.

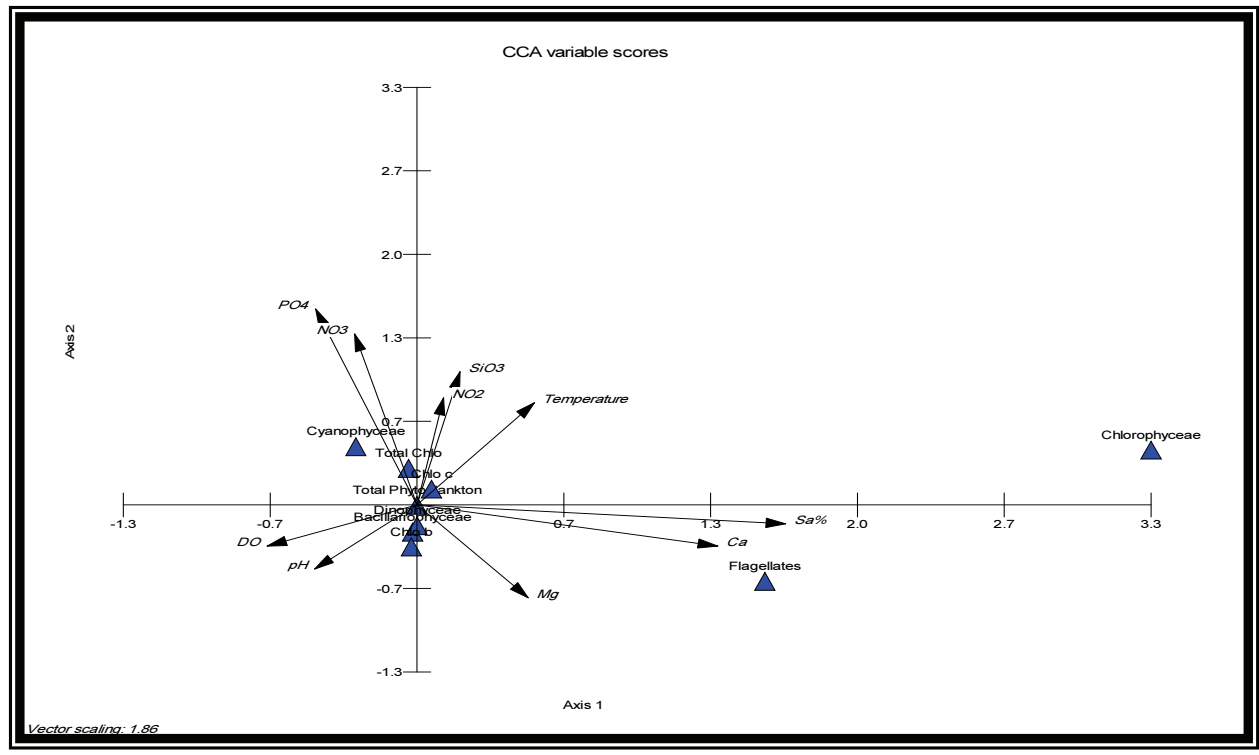

Fig. 5. Canonical Correspondence analysis (CCA) along the studied areas during the period of investigation.

These relations were reported by some authors as Millie et al.$^{[34]}$ for St. Lucie River Estuary, Florida (USA), Totti et al. ${ }^{[35]}$ at Cyanophyceae and dissolved oxygen. These relations were reported by some authors in the North Adriatic Sea by $\mathrm{Chen}^{[36]}$ at the South China Sea. Bacillariophyceae had a positive strong relation with dissolved oxygen and negative relation with silicate. The total phytoplankton appeared as floating parameters which is affected by most environmental parameters. It was positively correlated to Orthophosphate, Nitrite, Nitrate, Silicate and water temperature. On the other hand, it was negatively correlated to dissolved oxygen, $\mathrm{pH}, \mathrm{Mg}, \mathrm{Ca}$ and salinity. Water quality and phytoplankton dynamics mirrored seasonal hydrologic and salinity regimes throughout the Jeddah Coast of the Red Sea. According to the 
present investigation it can be concluded that Jeddah Coast is oligotrophic ecosystem with some of its area considered as mesotrophic due to sewage pollution as sites of Down Town area and South Jeddah Area. Finally, it can be concluded that rapid pollution growth and waste water discharged either directly or indirectly to the sea are the most serious problems of Jeddah Coast of the Red Sea.

\section{References}

[1] Edwards, A.J., Red Sea (1987) Pergamon Press, Oxford, pp. 45.

[2] Abdel Mohsen, A.F. and Bokary, H.A. (1969a) Bull. of Faculty of Science, Riyadh Univ. 1: 58.

[3] Abdel Mohsen, A.F. and Bokary, H.A. (1969b) Bull. of the Faculty of Science, Riyadh Univ. 1: 2.

[4] Abou El-Kheir, W.S. (1976) Annual Review Univ. Coll. For Girls, Ain Shams Univ. U.A.R. 9: 69.

[5] Aleem, A.A., Khafaji, A.K. and Bassam, B.A. (1982) Bull. of the Faculty of Science, King Abdulaziz Univ. Saudi Arabia, 6: 73.

[6] Abdul Aziz, P.; Al-Tisan, I.; Al-Daili, M.; Green, T.; Ghani, A. and Javeed, M. (2003) Desalination 132: 29.

[7] Khomayis, H.S. and Al-Harbi, S.M. (2003) J KAU: Mar. Sci, 14: 3.

[8] Khomayis, H.S. (2002) J KAU: Mar. Sci, 13: 131.

[9] Seeberg-Elverfeldta, I.; Langeb, C. and Pätzold, J. (2004) Marine Micropaleontology, 51: 193.

[10] APHA (American Public Health Association) (1992) Standard Methods for the Examination of Water and Wasterwater. 18th A.P.H.A., A.W.W.A., W.P.C.F. American Public Health Association 1015 pp. Fifteenth St. N.W. Washington D.C. 20005.

[11] Starmach, K. (1966) Tom 2 Polska Akademia NAUK.

[12] Cornelius, I.W. (1971) U.S. Environmental Protection Agency, National Environmental Research Center, Analytical Quality Control Lab. Cincinnati, Ohio.

[13] Garcia-Baptista, M. (1993) Bibliogtheca Phycologica Band 94. J. Cramer in der Gebruder Borntraeger Verlagsbuchhandlung Berlin. Suttgart 1993, 167.

[14] Silva, S.M.F. and Pienaar, R.N. (2000) Bibliogtheca Phycologica Band 107 J. Cramer in der Gebruder Borntraeger Verlagsbuchhandlung Berlin. Suttgart, 455.

[15] Botes, L. (2003) Saldanha Bay, South Africa. Marine and Coastal Management, Private Bag X2, Rogge Bay, Cape Town 8012, South Africa.

[16] Kovach, L. (2000) Kovach Computing Services, 3.12b.

[17] Ter Braak, C.J.F. (1986) Ecology, 67: 1167.

[18] Ter Braak, C.J.F. (1987) Vegetatio, 64: 69.

[19] Buzzi, F. (2002) Marine Pollution Bulletin, 32: 32.

[20] Kebede, E. Ahlgren, G. (1996) Hydrobiologia, 332: 99.

[21] Qijun, J.; Paeral, H.W. and Mallin, M.A., (1994) Marine Ecology Progress Series, 75. 133.

[22] Calliaria, D.; Gomez, M. and Gomez, N. (2005) Continental Shelf Research, 25 : 197. 
[23] Schumann, R.; Baudler, H.; Glass, A.; Dümcke, K. and Karsten, U. (2006) Journal of Marine Systems (article in press).

[24] Farag-Afaf, H.A. (2005) Ph.D. Thesis, Fac. Of Girls, Ain Shams Univ., (Egypt).

[25] Wu, J. and Chou, T. (2003) Estuarine, Coastal and Shelf Science 58: 155.

[26] Yousry-Karima, M. (2003) M.Sc. Fac. Of Girls., Ain shams university (Egypt).

[27] Donatella, R.J. (2005) $6^{\text {th }}$ ed. Pearson Education Inc.

[28] El-Bassat, R.A. and Taylor, W.D. (2007) African J. of Aquatic Science, 32(2): 185.

[29] Camargo, J.A. and Alonso, A. (2006) A global assessment Environ. Int., 32(6): 831.

[30] Aktan ,Y.; Tufekc,V.; Tufekc,H. and Aykulu, G., Estuarine (2005) Coastal and Shelf Science $64: 372$.

[31] Parnell, P. (2003) Marine Environmental Research, 55: 293.

[32] Varela, M. and Prego, R. (2003) Acta Oecologica, 24 : 113.

[33] Morais, P., Chícharo, M. and Barbosa, A. (2003) Acta Oecologica, 24: S87.

[34] Millie, D.F.; Carrick, H.J. ; Doering, K. P.H. and Steidinger, A. (2004) Coastal and Shelf Science 61: 137.

[35] Totti, C.; Cangini, M.; Ferrari, C.; Kraus, R.; Pompei, M.; Pugnetti, A.; Romagnoli, T.; Vanucci, S. and Socal, G. (2005) Science of the Total Environment, 353: 204.

[36] Chen, Y.L. (2005) Deep-Sea Research I, 52: 319.

[37] Taha, O.E., Abdel-Karim, M.S. and Sobhy, E.H. (2002) Red Sea Program-Final Report, 50 .

[38] Celekli, A. and Kulkoyluoglu, O. (2006) J. of Ecological indicators (article in press). 


\section{التركيب النوعي للهائمات النباتية في ساحل جدة - المملكة العربية السعودية - و علاقتها ببعض العو امل البيئية}

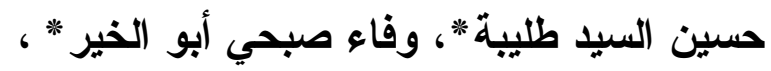

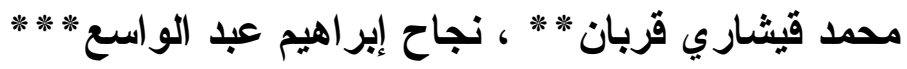
* قسم النبات - كلية البنات للآداب و العلوم و التنربية جامعة عين شدس - القاهرة - دصر

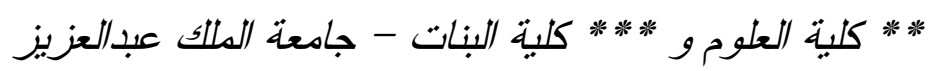

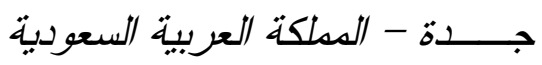

الدستخلص. تمت دراسة التغير ات في الهائمات النباتية وعلاقتهـــا

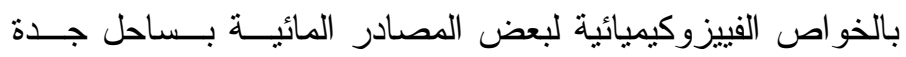

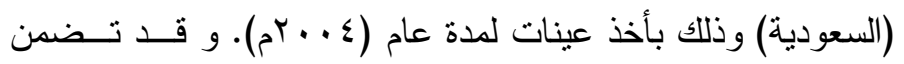

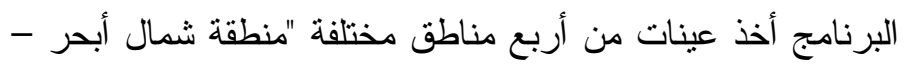

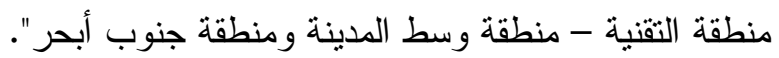

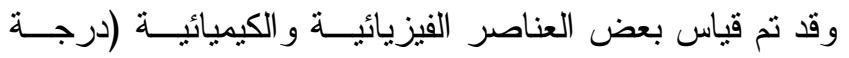

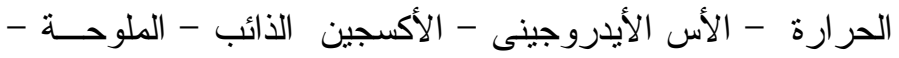

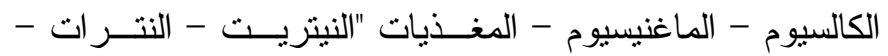

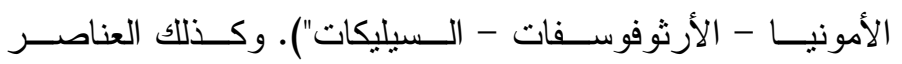

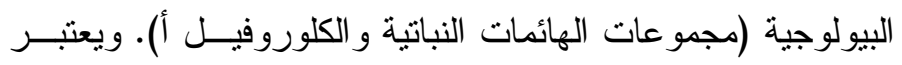

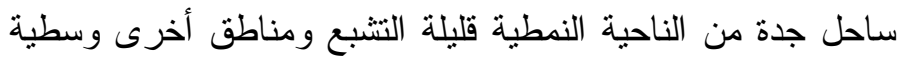
التثبع وكثافة عالية للهائمات النباتية خاصة في منطقة وسط المدينة

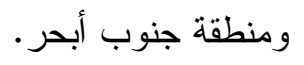

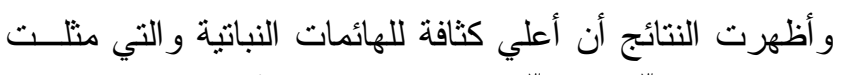

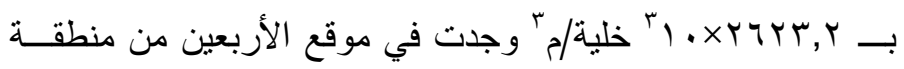

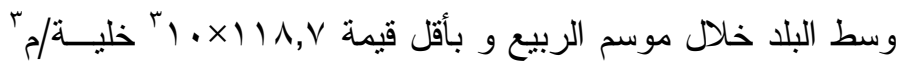


في موقع منطقة التقنية خلال موسم الثتاء. كما تم التعـرف علـي

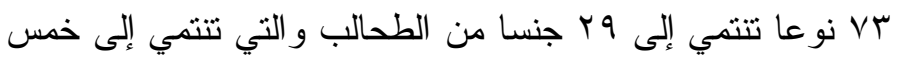
مجموعات هي السوطيات و التي احتلت مركز السيادة الأول بنسبة

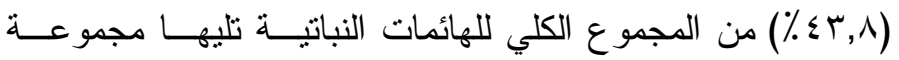

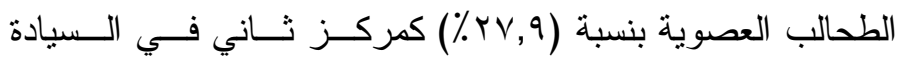
للهائمات النباتية بينما احتلت الطحالب الخضر اء المزرقة المركـز

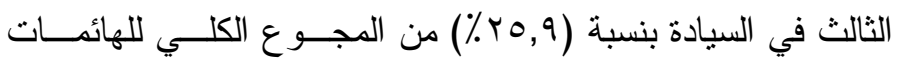
النباتية. أما مجموعة الطحالب الخضر اء و الطحالب الصفر اء احتلتا

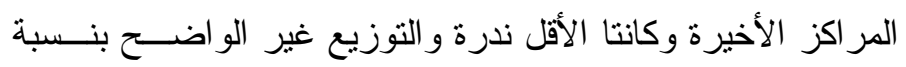

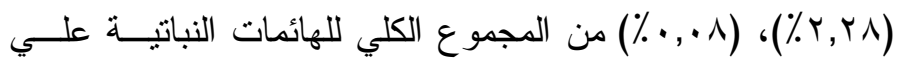
الترتيب ومثلت بنوع و احد وجنس و احد لكل منهما. وتعتبر الأنواع

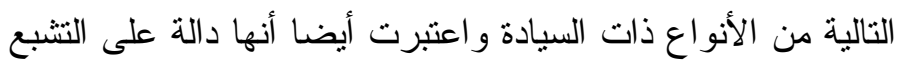
Ceratium sp. Amphora ovalis, Pleurosigma salinatum, Trichodesmium and Synochoccus sp. 